\title{
Base Composition of Deoxyribonucleic Acid from Ureaplasmas Isolated from Various Animal Species
}

\author{
C. J. HOWARD, D. H. POCOCK, AND R. N. GOURLAY \\ Agricultural Research Council, Institute for Research on Animal Diseases, Compton, Newbury, Berkshire \\ RG16 ONN, England
}

\begin{abstract}
The guanine-plus-cytosine $(\mathrm{G}+\mathrm{C})$ contents of the deoxyribonucleic acids (DNA) from ureaplasmas (T-mycoplasmas) isolated from several animal species were determined. The values obtained indicate that the $\mathrm{G}+\mathrm{C}$ content of ureaplasmas is within a range from 26.9 to $31.6 \mathrm{~mol} \%$. The distinctness of the DNA $\mathrm{G}+\mathrm{C}$ content of bovine isolates from that of Ureaplasma urealyticum (the human isolates) is confirmed. The values found for the DNA from canine and feline strains did not distinguish them from $U$. urealyticum. The caprine and ovine strains have DNA G+C contents similar to but slightly higher than those of the bovine strains. Although the strain isolated from a marmoset has a $\mathrm{G}+\mathrm{C}$ content that is within the range observed for bovine isolates, the strain isolated from a squirrel monkey has a $\mathrm{G}+\mathrm{C}$ content that falls between the ranges observed for human and bovine isolates. The results support the suggestion that more than a single species or subspecies exists within the genus Ureaplasma, but more evidence is needed before proposals for new taxa can be made.
\end{abstract}

Organisms considered to belong to the genus Ureaplasma, i.e., mycoplasmas with urease activity, have been isolated from a variety of species of animals. These include humans and nonhuman primates, cattle, dogs, cats, goats, and sheep $(10,17)$. At present a single species, $U$. urealyticum, has been proposed within the genus Ureaplasma. This is a serologically heterogeneous group, and eight representative strains, which are distinguishable by immunofluorescence and metabolism inhibition or growth inhibition tests but which may possess certain shared antigens in some instances, are included in it. All eight of these strains originate from humans $(2,12,14)$.

Previous studies of both antigenic structure and the guanine-plus-cytosine $(\mathrm{G}+\mathrm{C})$ content of deoxyribonucleic acid (DNA) have indicated that ureaplasmas isolated from cattle are also serologically heterogeneous, but are distinguishable from $U$. urealyticum by serological tests and $\mathrm{G}+\mathrm{C}$ content, and a group of representative strains of what might be a separate species or subspecies of $U$. urealyticum has been proposed $(3,8,9)$.

This study was initiated to determine the $\mathrm{G}+\mathrm{C}$ content of some of the representative bovine strains not examined previously and of certain ureaplasma strains isolated from other animal species to see how similar these were to the human or bovine isolates described previously.

The cloned ureaplasma strains used and the animal species from which they were isolated are listed in Table 1. Most of these strains have been described before; they were of bovine (8), human (14), feline (16), and caprine (4) origin. The canine and nonhuman primate strains were obtained from D. Taylor-Robinson (London), and the ovine strains were from G. Jones (Edinburgh).

All strains were grown in urea broth (8), and the DNA was extracted by a modification of the method of Marmur $(1,11)$. The $\mathrm{G}+\mathrm{C}$ content of the DNA was determined from its buoyant density after analytical equilibrium centrifugation in cesium chloride. Escherichia coli B DNA (Sigma Chemical Co., London) was used as reference $(9,13)$.

The $\mathrm{G}+\mathrm{C}$ contents of the DNA samples tested are given in Table 1. The bovine isolates examined here have a similar $\mathrm{G}+\mathrm{C}$ content to those previously described (9). The $\mathrm{G}+\mathrm{C}$ content of bovine ureaplasmas is within the range 28.7 to $30.2 \mathrm{~mol} \%$, taking into account both the results presented here and those previously reported. The value of $27.6 \mathrm{~mol} \%$ obtained for the human isolate (type VI) included as a control is within the range 26.9 to $28.0 \mathrm{~mol} \%$ previously established for $U$. urealyticum $(3,14)$. Thus the observation that strains of bovine ureaplasmas could be distinguished from $U$. urealyticum on the basis of the $\mathrm{G}+\mathrm{C}$ content of their DNA is confirmed.

The DNAs from ovine and caprine strains have $\mathrm{G}+\mathrm{C}$ values within the range 30.6 to 31.6 mol\%. These values indicate that the range of $\mathrm{G}+\mathrm{C}$ contents for ovine and caprine strains is 
TABLE 1. $G+C$ content of DNA from ureaplasmas isolated from several species of animals

\begin{tabular}{|c|c|c|c|}
\hline $\begin{array}{l}\text { Strain des- } \\
\text { ignation }\end{array}$ & Isolated from: & $\begin{array}{l}\text { Source or } \\
\text { reference }^{a}\end{array}$ & $\begin{array}{c}\mathrm{G}+\mathrm{C} \\
\text { content } \\
\text { (mol\%) }\end{array}$ \\
\hline G3 & & 1 & 31.6 \\
\hline G1 & Goat & 1 & 31.4 \\
\hline T515 & & 2 & 31.4 \\
\hline T516 & Sheep & 2 & 30.6 \\
\hline T95 & & 3 & 30.2 \\
\hline T71 & & 3 & 30.2 \\
\hline T315 & Cattle & 3 & 29.4 \\
\hline T288 & & 3 & 29.3 \\
\hline Mmb167 & & 3 & 28.7 \\
\hline My6690 & Marmoset & 4 & 29.6 \\
\hline Sp. $1625 A$ & Squirrel monkey & y 5 & 28.3 \\
\hline 382 & Cat & 6 & 27.9 \\
\hline Sp1701 & & 5 & 27.8 \\
\hline My5464 & Dog & 4 & 27.2 \\
\hline VI & Human & 7 & 27.6 \\
\hline
\end{tabular}

${ }^{a}$ (1) Gourlay et al., 1973; (2) G. Jones, Moredun Institute, Edinburgh, Scotland; (3) Howard et al., 1978; (4) D. Taylor-Robinson, M.R.C. Clinical Research Centre, Harrow, England; (5) Taylor-Robinson and Furr, 1973; (6) J. G. Markham, Dunedin Hospital, New Zealand; (7) Ureaplasma urealyticum, ATCC 27818, American Type Culture Collection, 12301 Parklawn Drive, Rockville, Md.

more similar to that of the bovine strains than that of $U$. urealyticum, the strains of human origin.

The DNA from canine and feline strains have $\mathrm{G}+\mathrm{C}$ values within the range observed for $U$. urealyticum. The strain isolated from a marmoset has a DNA G+C content that is within the range observed for bovine strains, whereas the value for the isolate from a squirrel monkey is between the range of values observed for bovine strains and $U$. urealyticum.

The $G+C$ content of the ureaplasma strains so far examined thus varies from 26.9 (strain VII of $U$. urealyticum [3]) to $31.6 \mathrm{~mol} \%$ (strain G3, Table 1), and the results obtained are consistent with the idea of dividing the ureaplasmas into groups. Although there appears to be a limited host range for ureaplasma strains (6) (i.e., some species specificity is evident), it would be inappropriate to use the species of animal from which a strain has been isolated for its classification. However, it is also inappropriate to apply to the ureaplasmas, without modification, the criteria proposed for defining species of typical mycoplasmas, for which the major factor is the absence of cross-reactions by certain serological tests (15). Thus, whereas $U$. urealyticum includes several serotypes, bovine ureaplasmas seem to exist as clusters of strains which are not identical but which share antigens $(2,7,8$, 14). Like strains of $U$. urealyticum, bovine urea- plasma strains can also be selected which do not cross-react with each other. Consequently, absence of serological cross-reactions between $U$. urealyticum and bovine ureaplasmas is insufficient evidence alone to propose a new species of Ureaplasma. Nevertheless, serological tests are still useful for determining the relation between strains, and the absence of cross-reactions between representative bovine and human strains has been noted $(7,8)$. It would seem that if both serology, based on examinations of a large number of strains, and some other criteria, e.g., G+C content, were taken into account, then a system for the classification of ureaplasmas might be possible. In the future, of course, another feature might be used.

There is no evidence from these studies to indicate that the canine and feline strains are sufficiently different from $U$. urealyticum to be regarded as a distinct species. The other ureaplasmas with a G+C content of $>28.5 \mathrm{~mol} \%$ and composed of the proposed representative bovine strains (8) together with strains isolated from goats, sheep, and a marmoset seem to constitute a group of organisms distinguishable from $U$. urealyticum. However, within this group the relation of the bovine strains to isolates from the other animal species needs to be considered further. It may be that the ovine and caprine strains should be included in a group with the bovine strains. Alternatively, as the ovine and caprine strains have $\mathrm{G}+\mathrm{C}$ contents slightly higher than the range observed for the bovine strains, it is possible that they might represent yet another distinguishable group of ureaplasmas. Insufficient data are available at present to make this decision. The relation of strains from nonhuman primates to each other and to the two proposed groups needs to be studied further.

\section{REPRINT REQUESTS}

Address reprint requests to: Dr. C. J. Howard, Agricultural Research Council, Institute for Research on Animal Diseases, Compton, Newbury, Berkshire RG16 ONN, England.

\section{LTTERATURE CITED}

1. Bak, A. L., and F. T. Black. 1968. DNA base composition of human T-strain mycoplasmas. Nature (London) 219:1044-1045.

2. Black, F. T. 1973. Modifications of the growth inhibition test and its application to human T-mycoplasmas. Appl. Microbiol. 25:528-533.

3. Black, F. T., C. Christiansen, and G. Askaa. 1972. Genome size and base composition of deoxyribonucleic acid from eight human T-mycoplasmas. Int. J. Syst. Bacteriol. 22:241-242.

4. Gourlay, R. N., J. Brownlie, and C. J. Howard. 1973. Isolation of T-mycoplasmas from goats, and the production of subclinical mastitis in goats by the intramammary inoculation of human T-mycoplasmas. J. Gen. Microbiol. 76:251-254. 
5. Howard, C. J., and R. N. Gourlay. 1973. Inhibition by normal rabbit sera of the growth of T-mycoplasma strains isolated from different animal species. J. Gen. Microbiol. 78:277-285.

6. Howard, C. J., R. N. Gourlay, and J. Brownlie. 1973. The virulence of $T$-mycoplasmas, isolated from various animal species, assayed by intramammary inoculation in cattle. J. Hyg. 71:163-170.

7. Howard, C. J., R. N. Gourlay, and J. Collins. 1975. Serological comparison between twenty-five bovine Ureaplasma (T-mycoplasma) strains by immunofluorecence. Int. J. Syst. Bacteriol. 25:155-159.

8. Howard, C. J., R. N. Gourlay, and J. Collins. 1978. Serological studies with bovine ureaplasmas (T-mycoplasmas). Int. J. Syst. Bacteriol. 28:473-477.

9. Howard, C. J., R. N. Gourlay, D. J. Garwes, D. H. Pocock, and J. Collins. 1974. Base composition of deoxyribonucleic acid from bovine T-mycoplasmas. Int. J. Syst. Bacteriol. 24:373-374.

10. Livingston, C. W., and B. B. Gauer. 1975. Isolation of $\mathrm{T}$-strain mycoplasma from sheep and goats in Texas. Am. J. Vet. Res. 36:313-314.

11. Marmur, J. 1961. A procedure for the isolation of deoxy- ribonucleic acid from micro-organisms. J. Mol. Biol. 3:208-218.

12. Piot, P. 1977. Comparison of growth inhibition and immunofluorescence tests in serotyping clinical isolates of Ureaplasma urealyticum. Br. J. Vener. Dis. 53: 186-189.

13. Schildkraut, C. L., J. Marmur, and P. Doty. 1962. Determination of the base composition of deoxyribonucleic acid from its buoyant density in $\mathrm{CsCl}$. J. Mol. Biol. 4:430-443.

14. Shepard, M. C., C. D. Lunceford, D. K. Ford, R. H. Purcell, D. Taylor-Robinson, S. Razin, and F. T. Black. 1974. Ureaplasma urealyticum gen. nov., sp. nov.: proposed nomenclature for the human $\mathrm{T}$ (Tstrain) mycoplasmas. Int. J. Syst. Bacteriol. 24:160-171.

15. Subcommittee on the Taxonomy of Mycoplasmatales. 1972. Proposal for minimum standards for descriptions of new species of the order Mycoplasmatales. Int. J. Syst. Bacteriol. 22:184-188.

16. Tan, R. J. S., and J. Markham. 1971. Feline T-strain mycoplasmas. Jpn. J. Exp. Med. 41:247-248.

17. Taylor-Robinson, D., and P. Furr. 1973. The distribution of T-mycoplasmas within and among various animal species. Ann. N.Y. Acad. Sci. 225:108-117. 